\title{
Building Intercultural Competence Through Intercultural Competency Certification Of Undergraduate Students
}

Maria G. Fabregas Janeiro, Oklahoma State University at Stillwater, USA Ricardo Lopez Fabre, INQBA, Puebla, Mexico

Jose Pablo Nuño de la Parra, UPAEP University, Puebla, Mexico

\begin{abstract}
The Intercultural Competency Certificate (CCI in Spanish) designed for the Universidad Popular Autónoma del Estado de Puebla (UPAEP University) is a theory based comprehensive plan to develop undergraduate students' intercultural competence. This Certificate is based in the Developmental Model of Intercultural Sensitivity (DMIS) developed by Milton Bennett (1993) and will be assessed by the Intercultural Development Inventory (IDI) v.3 developed by Bennett \& Hammer (Hammer, 2009; Hammer, Bennett, \& Wiseman, 2003). The main purpose of the Intercultural Competency Certificate is to develop students' intercultural competence at least to the acceptance level of the DMIS continuum. To achieve this goal, the students will have to develop of necessary knowledge, skill and attitudes (Deardorff, 2006). This Certificate proposes to develop attitudes, knowledge and skills through certain activities as learning a new language, take international classes, reflect about intercultural differences, interact with people from other cultures, travel abroad and receive coaching by a professional who will guide them through tailor-make experiences according to the initial level of intercultural competence, measured by the IDI v.3 at the beginning of the Certification.
\end{abstract}

Keywords: Certificate; Intercultural Competence; Developmental Model of Intercultural Sensitivity; Intercultural Development Inventory

\section{INTRODUCTION}



igher education institutions around the world are encouraging students to explore international and intercultural opportunities aiming to prepare them to face international and global challenges in their work places. Universities are diversifying and strengthening students' international and intercultural opportunities, by offering each year more short and long international programs, as Faculty Led experiences and semester long study abroad opportunities, as well as international and diversity courses (School of International Studies, 2011). However, isolated efforts are not improving students' intercultural competences (Fabregas Janeiro, 2009; Fabregas Janeiro, Kelsey \& Robinson, 2011). A comprehensive approach is needed to meet students' and future professionals' requirements of the 21 st Century. Diversification of activities, curriculum and pedagogical approaches should be adapted to support students' acquisition of intercultural competencies (Bhawuk \& Brislin, 1992; Rizvi \& Walsh, 1998; Stier 2006).

Comprehensive approaches like one taken by the University Of Central Oklahoma Center Of Global Competency's approach (UCO Center for Global Competency, 2009) could be more effective in developing intercultural competences. The Center for Global Competency provides the opportunity for students to earn a Certificate in Global Competence during their undergraduate studies. This certification entails different components to guarantee students' exposure to international and intercultural experiences. Yet, there is no evidence of any acquisition or improvement in students' intercultural competence, or the development or improvement of knowledge, skills or attitudes improvement as result of their participation in the Certification program at UCO (UCO Center for Global Competency, 2009). 
Other limitations in the institutional efforts to improve intercultural competence is that the majority of the institutional efforts may be or not be comprehensive but they are not theory based, and they based their success only by the number of students participating in different intercultural programs (Deardorff, 2004), and not in the students' development intercultural competence (Bennett, 1993; Bhawuk \& Brislin, 1992; Cant, 2004; Fabregas Janeiro et al., 2011; Hammer, 2009; Hammer et al., 2003). Deardorff (2004) discusses the ambiguity of the American institutions' conceptualization and assessment of intercultural competence.

In addition to the lack of comprehensive and theory based initiatives to improve students' intercultural competence, universities outside the United States also face challenges. While international students find it attractive to attend American colleges and universities, which can contribute to creating multicultural campuses, in Mexico, Mexican students have far fewer opportunities to interact with people from other cultures. The percentage of international students in Mexican institutions is less than 1\%. UPAEP University vision statement of 2011 started that preparing students for a global environment as a priority (Universidad Popular Autónoma del Estado de Puebla, 2011). UPAEP University's strong institutional commitment to develop intercultural competences among their students is showed and discussed in this study. This study discusses the UPAEP University's institutional efforts leading by the authors in designing a comprehensive theory-based intercultural competence development plan for undergraduate students, through the design a Certificado de Competencias Interculturales (CCI), Certificate of Intercultural Competence.

\section{THEORETICAL FRAMEWORK}

\section{UPAEP Vision 2015}

UPAEP University founded in 1973, is a private university located in Puebla, Mexico. It has four campuses in Mexico, Merida, Tehuacán, Tlaxcala and Puebla. UPAEP University offers 43 undergraduate programs, in four different areas, 1) individual development, 2) innovation and technology, 3) competitiveness, and 4) health. Its graduate college offers 34 Master programs, and 13 Doctoral programs. More than 10,000 students are enrolled at UPAEP University (UPAEP, 2011).

\section{Developing Intercultural Competences}

Higher education institutions are denoting active efforts to promote diversity "foster the exchange of ideas en experience among people of different heritages and believes" (Smithee, 1991, p. 8). Diversity institutions understands and appreciates the interdependence between cultures and human beings, and recognizes the need to relate with different people outside one's own racial or profile group (Iowa State University, College of Liberal Arts, 2011), while multicultural environments only recognize the presence of different groups of students (Caleb, 1996), and normally it is limited to ethnicity and race (Smithee, 1991).

One of the most important efforts of colleges and universities is the design of programs aiming to develop students' leadership and ability to interact with people from other cultures, and lead in global intercultural environments (Bhawuk \& Brislin, 1992; Caleb, 1998). These leaders must be prepared in a "mind-set, hear-set and skills-set that can carry across cultural boundaries" (Deardorff, 2009, p. 67).

Some academic programs have focused on developing in the university community intercultural sensitivity (IS) and intercultural competence (IC). Intercultural Sensitivity (IS) is defined as the ability to recognize, respect, and discriminate cultural differences and different points of view. IS was described by Bennett's $(1986,1993)$ Developmental Model of Intercultural Sensitivity (DMIS). Intercultural competence (IC) is defined as the ability to interact with people from other cultures, acting in intercultural appropriate ways (Hammer et al., 2003). IC requires the development of attitudes, skills and acquisition of knowledge. It is a life long process (Deardorff, 2009). IS could be an indicator of IC (Hammer et al., 2003; Hammer, 2009).

To contribute to the development of intercultural competence some authors recommend including in the curriculum activities and actions that could contribute to the development of five global cultural competencies: cultural consciousness, cultural self-awareness, global mindset, and the abilities to lead and negotiate in 
multicultural teams (Ashwill, 2004; Cant, 2004). Other authors include models of development of intercultural competent skills, knowledge and attitudes (Deardorff, 2009). However, in most cases higher education institutions just rely on their students' development of intercultural competences by promoting multicultural activities around campuses and supporting students' participation in short or long term study abroad experiences. These efforts are isolated and basically focused in recruiting international and intercultural students. The aim of universities is to create a multicultural college environment, and expose local students to international environments, through study abroad experiences (Anderson, 2004; Caleb, 1998; Fabregas Janeiro, 2009; Mark, 2004; Medina-Lopez-Portillo, 2004). However, it has been proved that these isolate efforts have not been enough to impact higher education intercultural competence. Comprehensive and theory base efforts have been suggested as an alternative (Fabregas Janeiro, Kelsey, \& Robinson, 2011).

Universities outside the United States, like UPAEP face another challenge, these universities have very limited number of international students enrolled on their campuses, therefore interactions with people from other cultures is very limited. For numerous Mexicans intuitions the only ways to promote the development of intercultural competences is taking students outside their campuses in short or long study abroad experiences or designing aggressive comprehensive programs to develop intercultural competences (Fabregas Janeiro, 2009).

\section{Theory Based Comprehensive Programs to Develop Intercultural Competence}

It has been discussed that institutions of higher education need to develop strategic theory based comprehensive plans to become intercultural competent communities. It will never be enough just to attract international students to the campuses, or to design cultural nights and international food courts (Ashwill, 2004). A theory based comprehensive plan to develop intercultural competencies should include the acquisition of certain skills, and changing attitudes and behaviors as proposed by different intercultural competence theories and models (Deardorff, 2009; Fabregas Janeiro et al., 2011).

The contemporary models of intercultural competence described by Deardorf (2009), include, (a) compositional models, (b) co-orientational models, (c) developmental models and (d) adaptational models. Compositional Models designed by Howard Hamilton, (1998), Ting-Toomey and Kurogi (1998) and Deardorf (2006), cited by Deardoff (2009) suggested the development of knowledge, attitudes and skills. Co-orientational models conceptualized "interactional achievement of intercultural understanding or any of its variants" (p. 10). Developmental models consider the possibility of achieving intercultural competence going through certain stages of progression. Adaptational models emphasize interdependence of "multiple interacts by modeling the process of mutual adjustment" (p. 10).

Compositional models could be combined with developmental models. The participants in the CCI can develop knowledge, attitudes and skills while they move from one stage to another to increase their interucultural competences. Desing activities that develop knowledge and comprehension, atitudes and skills as described by Dearrdoff (2006) in the Compositional-Pyramidal Model of Intercultural Competence (Deardoff, 2006); discuss and experience cultural differences while moving from ethonocentric to ethnorelative stages as proposed by the Developmental Model of Intercultural Sensitivity (DMIS) developed by Bennett (1993). The main goal of DMIS is developing strong and long term theory based strategic comprehensive plans that could include different activities such as international courses, teaching abroad, Fulbright experiences, faculty led experiences, language training, short and long faculty led experiences, international courses, and/or diversity courses (Anderson, 2004; Busby, 1993; Emert, 2008; Fabregas-Janeiro, 2009; Fabregas Janeiro et al., 2011; Fretheim, 2007). The DMIS provided the theoretical framework to develop the Intercultual Development Inventory (IDI) (Hammer et al., 2003), this instrument assess cultural competence. The combination of these two models and the use of the IDI to asess interculturla competenece could result in a comprehensive theory base approach to develop intercultural competence suggested by Fabregas Janeiro et at. (2011).

\section{Institutional Approaches to Develop Intecultural Competences}

Institutions in the United States that have integrated different intercultural activities with the objective of developing student intercultural competencies, include variety of activities, such as promoting language learning, 
studying abroad experiences, and attending international events (Emert, 2008; Fabregas Janeiro et al., 2011; Fretheim, 2007; Golay, 2006; Herbst, 2011; Jeffrey, 2007; Keefe, 2008; Mark, 2004; Medina-Lopez-Portillo, 2004). The impact of the majority of the programs is not significant or developmental, as discussed by Milton Bennett (1993). For example, Boston College designed a Global Proficiency program, that had three requirements; an international experience, academic component (including language courses), and a co-curricular component (extracurricular activities) (Ashwill, 2004). Global proficiency programs suggest that achieving language proficiency is a good starting point to becoming truly bi-cultural, but cultural competence is distinct from language proficiency. California State University offers a Certificate of Language and Cultural Competence. To obtain this Certificate the students have to show their oral, writing, and reading skills in a second language, as well as their knowledge of history, current affairs and culture where the language they learned is spoken, as well as writing some essays to demonstrate their understanding of global issues. The program is evaluated assessing students' skills and knowledge thought the STAN Language assessment test, and other history and world affairs tests (Ashwill, 2004; California State University, 2011). Another example is the international strategy of Howard Community College to improve students' intercultural competence. The international strategy of the college includes a language program, a partnership with a foreign government, working with local business and industries, scholarships for students choosing international experiences, and building connections with other countries like China (Connell, 2006), this internationalization program was recognized and reported by the Association of International Educators (NAFSA) and included seven academic divisions and disciplines, and the opening of a Multicultural Resource Center where the students share their international experiences (Association of International Educators (NAFSA). However, there is no reported evidence of the impact of any of these plans in the students' intercultural sensitivity or competence (Ashwill, 2004; California State University, 2011; Emert, 2008; Fabregas Janeiro et al., 2011; Fretheim, 2007; Golay, 2006; Herbst, 2011; Jeffrey, 2007; Keefe, 2008; Mark, 2004; Medina-Lopez-Portillo, 2004). To develop significant impact on students' development of intercultural competences, it is recommended that higher education institutions integrate a comprehensive, theory based developmental plan, focused in the desired external and internal outcomes (Bennett, 1986, 1993; Deardorff, 2006), as part of the institutional strategic comprehensive intercultural development efforts.

\section{DEVELOPING A COMPREHENSIVE INTERCULTURAL COMPETENT PLAN FOR UPAEP UNIVERSITY IN MEXICO (CCI in SPANISH)}

\section{Definition \& General Objective}

Universidad Popular Autónoma del Estado de Puebla (UPAEP University) recognizes the importance of intercultural education. The development of intercultural competences in undergraduate students and faculty members will prepare them to respect the human rights and fundamental freedoms, as well as promoting the understanding, acceptance and friendship among all nations. To contribute to the development of intercultural competences, UPAEP has designed a Certificado de Competencias Interculturales (CCI) -Intercultural Competency Certificate. CCI is a public recognition to Universidad Popular Autónoma del Estado de Puebla's students' interest in studying other cultures. This certificate also recognizes the interest and achievement of students in developing the required skills that will allow them to interact effectively with people from other cultures, whether in business, humanitarian aid or development of social programs (UNESCO, 2005).

\section{Development of the Program}

The CCI was designed to respect students' cultural identity, and teach them the required skills, attitudes, knowledge and values to respect a diverse society, contributing to the, understanding and solidarity among people from different ethnicities, social, cultural and religious values. The learning objectives of this program are, 1) Understand their own culture, 2) Identify cultural differences, 3) Understand the importance of living in a diverse society, and 4) Respect people from different cultures. The Intercultural Competency Certificate focuses in the development of knowledge and comprehension, skills and attitudes. 
To complete the Certificado de Competencias Interculturales (CCI in Spanish) - Intercultural Competency Certificate the students will:

1) Learn with mastery a second language to an intermediate-advanced level. Learning another language will increase students' global understanding. The students will be introduced inside another culture that will help them to have a different vision of life (Federico Fellini), Learning another language will enhance students' travel experience during the program (Marcos, 1999; World Language Symposium, 2009).

2) Approve the course: Living in a Diverse Society, the goal of this course is to reflect about the importance of achieving intercultural competence while gaining an understanding of the importance of developing appropriated skills to live and work in multicultural and diverse societies. This course has been taught for 4 years at Oklahoma State University. The course started understanding your own culture and the importance of living in a diverse society.

3) Take at least two international related classes. To increase their knowledge of global issues and concerns. The students will be able to choose from more than 20 different options, International Business, World History and Geography, International Trade, etc. The topics discussed in the class will help students to identify cultural differences and to learn about international competitiveness (Moran, 1997; Moran, Harris, \& Moran, 2010; Peterson, 2004).

4) Serve as support staff in UPAEP International Programs, working at least 100 hours with international students. The students will be in contact with international students, this experience will provide the students the abilities to recognize cultural differences, and the required skills to Identify cultural differences, and respect people from different cultures (Mäenpää, 2013; Ryan, 2011).

5) Participate in an International Exchange Program (Faculty Led, Semester Long Study Abroad, or Internship) at least for 3 months. Students traveling abroad change the way they see the world. Traveling increases your self-confidence, helping to understand your own culture. Traveling makes you aware of cultural differences and increases your ability to change your behavior in order to respect them (Anderson, 2004; Connell, 2006; Herbst, 2011; Keefe, 2008).

6) Keep a journal of their experience since the enrollment in the program. This journal should be a reflective journal about intercultural differences. Reflecting about your experiences will give this certificate an advantage over just typical instruction. The journal will help students to reflect in their own culture, the importance of living in a diverse society, respect of cultural differences (Angelico-Hart, 1997).

7) Write a final essay - capstone about students' experience. The essay will reflect a summary of their experience.

Each student will be assigned with an "Intercultural Competence Coach." This coach will guide the student during their intercultural development process, the coach will work with the students to identify personal goals, and to assist them in reflecting about cultural differences. The students' coach will discuss with the students their Intercultural Development Inventory evaluation, and will help students to achieve the goal the acceptance level of the DMIS continuum. The coaching could be done in person, by videoconference or by other electronic media. The coaches will be required to be certified in the Intercultural Development Inventory (IDI) v. 3 and will also receive training in the Achieve Coaching Model (Dembkowski \& Eldridge, 2006). However, the coaches will be free to decide the coaching model they would like to use during the sessions. The coach will review the initial intercultural sensitivity assessment (IDI) and will suggest special activities according to the student's intercultural development stage. The coach must meet with the student at least once a month. The goal is to help students to achieve the acceptance stage of the Developmental Model of Intercultural Sensitivity (DMIS) continuum suggested by Bennett (1993).

\section{Requirements to Participate in the Program}

The requirements to participate in the program are:

1) Be enrolled in one of the undergraduate programs at UPAEP University

2) Minimum GPA of 9.0 in a 10.0 scale

3) Complete the application package

4) Write an essay (1000 words minimum) about the importance of the development of intercultural competences 
5) Complete Intercultural Development Inventory (IDI) before and after the experience (Hammer, 2009; Hammer et al., 2003)

6) Be admitted to the program by the Program Committee

\section{Public Recognition}

The students that complete the Intercultural Competency Certificate (CCI in Spanish), will receive a Certificate of recognition in an annual formal special academic ceremony, chaired by UPAEP University Rector, with the presence of senior executives of global and multinational companies in the region. It is also suggested that in UPAEP commencement ceremony the students who received the certificate should also be recognized when they receive their degree.

\section{Evaluation of the Program}

The program will be evaluated by the accomplishment of the activities, and the change in intercultural competence measured by the Intercultural Development Inventory (IDI) (Hammer, 2009; Hammer et al., 2003) before and after the program. The student participants in the program will be motivated to achieve the Acceptance stage of the DMIS continuum described by Bennett (1993).

\section{CONCLUSION AND RECOMMENDATIONS}

In conclusion, the Certificado de Competencia Intercultural (CCI) - Intercultural designed for the Universidad Popular Autónoma del Estado de Puebla (UPAEP University) is based on compositional and developmental models which supports a comprehensive plan to develop undergraduate students' intercultural competence. It is also a theory base certificate based on the Developmental Model of Intercultural Sensitivity (DMIS) developed by Milton Bennett (1993). Further, the assessment of improvements in the students' intercultural competence is measure by the Intercultural Development Inventory (IDI) v.3 developed by Bennett \& Hammer (Hammer, 2009; Hammer et al., 2003). The main purpose of the Certificate training is to develop students' intercultural competence at least to the acceptance level of the DMIS continuum. However due the confidentiality of the IDI, the students' intercultural evaluation will not only be used to grant the Certificate. Students enrolled in the CCI will be engage in learning a new language, take international classes at UPAEP Campus, reflect about intercultural differences, interact with people from other cultures, travel abroad, , and receive professional coaching. Receipt of the CCI indicates that the student has attained a high level of skill in knowing their own culture, cultural differences, and engages in respect for people from other cultures. The author's recommendations is to put special emphasis he student initial stage of the DMIS measured by the IDI v.3 and to coach them according to their stage in the continuum. The students' reflective journals should students' own limitations, weakness and strengths through the developmental process.

\section{AUTHOR INFORMATION}

Dr. Maria G. Fabregas Janeiro is a Clinical Assistant Professor, Multicultural \& Community Engagement College of Human Sciences, Oklahoma State University at Stillwater, Oklahoma. E-mail: Lupita.Fabregas@okstate.edu (Corresponding author)

Dr. Ricardo Lopez Fabre is the Academic Director In-Q-ba Quinto Retorno. Circuito Osa Menor No. 4 Reserva Territorial Atlixcayotl at San Andrés Cholula, Puebla. México. E-mail: Ricardo.Lopez@inqba.edu.mx

Dr. Jose Pablo Nuño de la Parra is Director of Strategic Projects for the Graduate College at UPAEP University, Puebla, Puebla. México. E-mail: Pablo.Nuno@upaep.mx 


\section{REFERENCES}

1. Anderson, H. A. (2004). The development of multicultural competence: A cross-institutional analysis of contributory factors among undergraduate college students. Ed.D. 3131252, Azusa Pacific University, United States -- California. Retrieved from http://proquest.umi.com/pqdweb?did=765928181\&Fmt=7\&clientId=4653\&RQT=309\&VName=PQD

2. Angelico-Hart, D. (1997). Effects of reflective journal writing on classroom practices resulting from a staff development workshop: A qualitative study. University of Massachusetts Lowell. ProQuest Dissertations and Theses. Retrieved from http://search.proquest.com/docview/304382946?accountid=4117. (304382946)

3. Ashwill, M. (2004). Developing intercultural competence for the masses. International Educator, 13(2), 16.

4. Bennett, M. J. (1993). Toward ethnorelativism: A developmental model of intercultural sensitiviey. In R. M. Paige (Ed.), Education for the intercultural experience (pp. 21-71). Yarmouth, MW: Intercultural Press.

5. Bhawuk, D. P., \& Brislin, R. (1992). The measurement of intercultural sensitivity using the concepts of individualism and collectivism. International Journal of Intercultural Relations, 16(4), 413-436.

6. Busby, S. (1993). Transnational education and training: Myths, mobility and intercultural competence. European Business Review, 93(2), 11.

7. Caleb, R. (1996). What makes a school multicultural? Retrieved from http://www.edchange.org/multicultural/papers/caleb/multicultural.html

8. California State University. (2011). Global learning profiles, 2011. Retrieved from http://www.acenet.edu/AM/Template.cfm?Section=Home\&Template=/CM/HTMLDisplay.cfm\&ContentI $\mathrm{D}=1576$

9. Cant, A. G. (2004). Internationalizing the business curriculum: Developing intercultural competence. The Journal of American Academy of Business, 5(1/2), 177-182.

10. Connell, C. (2006). Educating citizens of the world. International Educator, 15(2), 36.

11. Deardorff, D. K. (2004). In search of intercultural competence. International Educator, 13(2), 13-15.

12. Deardorff, D. K. (Ed.). (2009). The sage handbook of intercultural competence. (2009). Thousand Oaks, CA: Sage.

13. Dembkowski, S., \& Eldridge, F. (2006). The achieve coaching model - A systematic approach to greater effectiveness in executive coaching. A Worldwide Association of Busines Coaches. Business Coaching Worldwide, 2(1). Retrieved from http://www.wabccoaches.com/bcw/2006_v2_i1/feature.html

14. Emert, H. (2008). Developing intercultural competence through teaching abroad with Fulbright: Personal experience and professional impact. Ph.D. 3308089, University of Minnesota, United States -- Minnesota. Retrieved from http://proquest.umi.com/pqdweb?did=1500060821\&Fmt=7\&clientId=4653\&RQT=309\&VName=PQD

15. Fabregas Janeiro, M. G. (2009). Assesing changes in intercultural sensitivity in students exposed to intercultural experiences supported by the College of Agricultural Sciences and natural resources at Oklahoma State University using the intercultural development inventory.(Ph.D. Dissertation). Oklahoma State University, Stillwater, OK. Retrieved from http://gradworks.umi.com/34/49/3449107.html

16. Fabregas Janeiro, M. G., Kelsey, K. D., \& Robinson, J. S. (2011). Assesing changes in intercultural sensitivity among agricultural students exposed to international experiences. Journal of International Agricultural and Extension Education, 18(1), 34-44.

17. Fretheim, A. (2007). Assessing the intercultural sensitivity of educators in an American international school. (Ed.D. Dissertation). University of Minnesota, MN. Retrieved from http://proquest.umi.com/pqdweb?did=1441185861\&Fmt=7\&clientId=4653\&RQT=309\&VName=PQD

18. Golay, P. A. (2006). The effects of study abroad on the development of global-mindedness among students enrolled in international programs at Florida State University. (Ed.D. Disertation). The Florida State University, FL. Retrieved from http://proquest.umi.com/pqdweb?did=1216756091\&Fmt=7\&clientId=4653\&RQT=309\&VName=PQD

19. Hammer, M. R. (2009). The intercultural development inventory. In M. A. Moodian (Ed.). Contemporary Leadership in Intercultural Competence (pp. 203-218). Thousand Oaks, CA: Sage.

20. Hammer, M. R., Bennett, M. J., \& Wiseman, R. (2003). Measuring intercultural sensitivity: The intercultural development inventory. International Journal of Intercultural Relations, 27(4), 421-443. doi: DOI: $10.1016 / \mathrm{S} 0147-1767(03) 00032-4$

21. Hammond, S. A. (1998). The thin book of appreciative inquiry. Bend, OR: Thin Book. 
22. Herbst, M. T. (2011). Building a faculty-led study abroad program: From development to history pedagogy in Istanbul. History Teacher, 44(2), 209-226.

23. Iowa State University. College of Liberal Arts. (2011). Retrieved from http://www.las.iastate.edu/about/diversity/definition.shtml

24. Jeffrey, S. (2007). An immersion program in language and culture, Ukrainian Weekly, p. S3. Retrieved from

http://proquest.umi.com/pqdweb?did=1278401721\&Fmt=7\&clientId=4653\&RQT=309\&VName=PQD

25. Keefe, M. (2008). Short-term study abroad: Impact on the development of global competencies at a public college of art and design in the northeast. (Ed.D. Disertation). Johnson \& Wales University, RI. Retrieved from

http://proquest.umi.com/pqdweb?did=1674956041\&Fmt=7\&clientId=4653\&RQT=309\&VName=PQD

26. Mäenpää, K. (2013, Feb 01). Finnish universities welcome international students. The Finnish American Reporter. Retrieved from http://search.proquest.com/docview/1287286517?accountid=4117

27. Mark, A. A. (2004). Developing intercultural competence for the masses. International Educator, 13(2), 16.

28. Marcos, K. (1999). Decade of the brain: Learning another language offers both personal and professional benefits. American Language Review, 3(6), 23-25.

29. Medina-Lopez-Portillo, A. (2004). College students' intercultural sensitivity development as a result of their studying abroad: A comparative description of two types of study abroad programs. (Ph.D.

Disertation). University of Maryland, Baltimore County, MD. Retrieved from http://proquest.umi.com/pqdweb?did=766275361\&Fmt=7\&clientId=4653\&RQT=309\&VName=PQD

30. Moran, N. (1997, Oct 01). Knowledge management, ways to gain competitive edge. Financial Times. Retrieved from http://search.proquest.com/docview/248559277?accountid=4117

31. Moran, R. T., Harris, P. R., \& Moran, S. V. (2010). Managing cultural differences: Global leadership strategies for the 21st Century (8th Ed.). Burlington, MA: Butterworth-Heinemann.

32. NAFSA: Association of International Educators. (2011). Internationalizing the campus: A NAFSA report

Howard Community College. Oklahoma State University. Office of international students and scholars.

Retrieved from http://union.okstate.edu/iss/

33. Peterson, B. (2004). Cultural intelligence: A guide to working with people from other cultures. Yarmouth, Main: Intercultural Press.

34. Rizvi, F., \& Walsh, L. (1998). Difference, globalization and the internationalization of curriculum. Australian Universities' Review, 41(2), 7-11. Retrieved from http://search.proquest.com/docview/62439277?accountid=4117

35. Ryan, J. (2011). Teaching and learning for international students: Towards a transcultural approach. Teachers and Teaching: Theory and Practice, 17(6), 631-648. Retrieved from http://search.proquest.com/docview/964189741? accountid=4117

36. School of International Studies. (2011). Welcome to OSU's study abroad/national student exchange office. Retrieved from http://ieo.okstate.edu/ieo.aspx?page $=16$

37. Stier, J. (2006). Internationalization, intercultural communication and intercultural competence. Journal of Intercultural Communication, (11) Retrieved from http://search.proquest.com/docview/61631896?accountid=4117

38. UCO Center for Global Competency. (2009). Center for Global Competency. Retrieved June 8, 2009, from www.uco.edu/cgc

39. UNESCO. (2005). Declaracion universal sobre bioetica y derechos humanos, 2011. Retrieved from http://portal.unesco.org/es/ev.php-URL_ID=31058\&URL_DO=DO_TOPIC\&URL_SECTION=201.html

40. UPAEP. (2011). Vision 2015, 2011. Retrieved from http://www.upaep.mx/index.php?option=com_content\&view=article\&id=395\&Itemid=4

41. World language symposium at Ramapo College celebrates benefits of learning another language. (2009, Apr 10). US Fed news service, including US State news. Retrieved from http://search.proquest.com/docview/470220495?accountid=4117 